The Law of Obligations in Europe 
(c) sellier european law publishers www.sellier.de 


\title{
The Law of Obligations in Europe
}

A New Wave of Codifications

\author{
edited by \\ Reiner Schulze \\ Fryderyk Zoll
}

$\mathbf{s}|\mathbf{e}| \mathbf{l} \mid \mathbf{p}$

sellier european law publishers 
ISBN (print) 978-3-86653-246-5

ISBN (eBook) 978-3-86653-983-9

The Deutsche Nationalbibliothek lists this publication in the Deutsche Nationalbibliografie; detailed bibliographic data are available on the Internet at http://dnb.dnb.de.

(C) 2013 by sellier european law publishers $\mathrm{GmbH}$, Munich

All rights reserved. No part of this publication may be reproduced, translated, stored in a retrieval system or transmitted, in any form or by any means, electronic, mechanical, photocopying, recording or otherwise, without prior permission of the publisher.

Production: Karina Hack, Munich. Printing and binding: AZ Druck und Datentechnik $\mathrm{GmbH}$, Kempten. Printed on acid-free, non-ageing paper. Printed in Germany.

(c) sellier european law publishers

www.sellier.de 